\title{
IDŐJÁRÁS
}

Quarterly Journal of the Hungarian Meteorological Service

Vol. 125, No. 4, October-December, 2021, pp. 675-692

\section{Future temperature and urban heat island changes in Budapest: a comparative study based on the HMS-ALADIN and SURFEX models}

\author{
Gabriella Allaga-Zsebeházi \\ Hungarian Meteorological Service \\ P.O. Box 38, H-1525 Budapest, Hungary \\ Corresponding author E-mail: zsebehazi.g@met.hu
}

\begin{abstract}
Cities, due to their warmer and dryer local climate in addition to their dense population, are subjected to large future climate change risks. Land surface models, with detailed urban parameterization schemes, serve as an adequate tool to refine the rough regional climate projections over the cities. In this study, the future temperature conditions in Budapest are studied with the SURFEX land surface model (LSM), driven by the HMSALADIN5.2 regional climate model (RCM) and considering the high-emission RCP8.5 scenario. Special attention is dedicated to explore the differences between the RCM and LSM in terms of the results, their interpretation, and further use in impact models. According to the investigated model combination, the winter season may warm the most, with $1.9^{\circ} \mathrm{C}$ in $2021-2050$ and $4.3^{\circ} \mathrm{C}$ in $2071-2100$, although the magnitude of this change is smaller in SURFEX than in ALADIN. Besides the mean changes, four climate indices, based on high and low temperature thresholds, were studied, and it was found that the low temperature indices (frost days and very cold days) may relatively decrease more in SURFEX compared to ALADIN over Budapest, and in the city center compared to the suburbs and rural areas. In addition, the urban heat island (UHI) intensity is projected to decrease in SURFEX mainly in spring and summer (by 2071-2100 with $0.35^{\circ} \mathrm{C}$ and 0.32 ${ }^{\circ} \mathrm{C}$, respectively). Finally, a simple method is provided to correct the SURFEX temperature fields, using the ALADIN model, with eliminated systematic biases and the simulated UHI field.
\end{abstract}

Key-words: urban climate, urban heat island, climate projection, land surface model, regional climate model 


\section{Introduction}

The physical characteristics of cities (i.e., impervious surfaces, large heat capacity, narrow streets, high buildings) in addition to their anthropogenic activities (e.g., internal heating and transportation) result in warmer, drier, and more polluted air in cities than in natural areas (Oke, 1982). One of the most studied phenomena of urban climate is the urban heat island (UHI), the temperature difference between the city and its environment, which is the largest at summer calm nights. Such unfavorable conditions may be exacerbated in the future due to climate change (Revi et al., 2014), which - align with the increasing population (UN, 2014) -, expose cities to severe heat related risks in the future.

Future climate change in urbanized areas is assessed at several levels of complexity. Wilby (2008) applied a statistical downscaling approach on general circulation models and revealed that the nocturnal UHI of London may be further strengthen by 2050 considering a medium-high (A2) emission scenario. Similar conclusion was drawn for the British cities by Lo et al. (2020) using HadREM3-GA7-05 (the regional climate configuration of the Hadley Centre Global Environmental Model), and for Berlin by Langendijk et al. (2019) using a subset of RCM simulations achieved in the frame of the Euro-CORDEX (the European branch of the Coordinated Regional Downscaling Experiments). In contrast, Lauwet et al. (2015) showed that the nocturnal UHI will decrease in the future based on the UrbClim urban boundary layer model simulations. This is reinforced by Hamdi et al. (2014), using the SURFEX (Surface Externalisée) land surface model (LSM) in offline mode driven by the ARPEGE-Climat (Action de Recherche Petite Echelle Grande Echelle-Climat) global climate model (the offline mode means, that the interaction between the GCM and the RCM is one-way). Therefore, the future change of UHI intensity is uncertain and more research is needed to better explore and understand the contributing physical processes.

In the Carpathian Basin, Budapest is the most populated capital, with its 1.75 million inhabitant and $525 \mathrm{~m}^{2}$ territory (Tatai et al., 2018). In the downtown of the city, the population density is between 10000 and 20000 people $/ \mathrm{km}^{2}$, while its outer rim is less built-in (here the population density does not exceed 20002500 people $/ \mathrm{km}^{2}$ ).

From 1901 to present, the annual mean temperature has increased more than $1.1^{\circ} \mathrm{C}$ in Budapest, which is comparable with the county-wise warming (Tatai et al., 2021). However, considering the change of extreme events, the frequency of warm temperature extremes has increased much more in Budapest, compared to the measurements of other centennial stations in Hungary. E.g., between 1901 and 2009, the number of heatwave days (Table 1) and hot days (when the maximum daily temperature reaches $30^{\circ} \mathrm{C}$ ) has increased 17 and 11 days, respectively, while the second largest increase is 13 days in case of heatwave days (in Szombathely, situated in the western part of Hungary) and 8 days in case of hot days (in Szeged, situated in the southern part of Hungary, Lakatos and Bihari, 2011). Therefore, 
the UHI effect superimposed on the regional climate change may explain the outstanding increase of warm temperature indices in the capital. Moreover, Dian et al. (2020) showed that the summer surface temperature in the downtown of Budapest may be $5{ }^{\circ} \mathrm{C}$ warmer compared to rural areas. The contribution of urbanization to regional climate change has been quantified in Bassett et al. (2020), and it was found that the cities' expansion in Great Britain between 1975 and 2014 explains $3.4 \%$ of the mean warming that reach up to $9.8 \%$ at the heavily urbanized southeastern part of the country.

At the Hungarian Meteorological Service (HMS), the SURFEX model is used for urban climate modeling in offline mode coupled to the HMS-ALADIN5.2 (the 5.2 version of the Aire Limitée Adaptation dynamique Dévéloppement International RCM adapted at the HMS). This model chain has been previously subjected to thorough validation, regarding the spatial and temporal characteristics of surface and $2 \mathrm{~m}$ UHI (SUHI and UHI, respectively), and it was found that compared to satellite measurements, SURFEX overestimates the SUHI extent especially during the day (Zsebeházi and Mahó, 2021). However, gridpoint validation with respect to station measurement showed that inherited from the driving ALADIN model, the LSM heavily overestimates the summer mean temperature, but apart from this and from the aspect of UHI, the model reasonably simulates urban temperature characteristics (Zsebeházi and Mahó, 2021; Zsebeházi and Szépszó, 2020).

Following the validation process, the SURFEX was applied for projection simulations, i.e., experiment covering the 1950-2100 period was achieved, taking into account the high-emission RCP8.5 scenario (Riahi et al., 2011). The urban climate projection may contribute to impact studies (e.g., in the field of health and tourism) to provide a more detailed realizations of future meteorological conditions, than an RCM is capable for. However, all models are loaded with biases, that are usually corrected before implemented in the impact model (Ehret, 2012). Since the resolution of an LSM $(\sim 1 \mathrm{~km})$ may be higher with at least one order compared to the gridded observational datasets, generally used for correcting the RCMs $(\sim 10 \mathrm{~km})$, such post-processing of urban climate simulation require somewhat new methods compared to the classical methodology developed for RCMs and GCMs.

The aim of this paper is 1) to assess the future climate change of Budapest from the aspect of temperature and UHI, 2) to explore how different the projected changes are compared to the ALADIN, and 3 ) to provide a simple postprocessing method to eliminate the biases of SURFEX.

In Section 2, the SURFEX and ALADIN models are briefly presented, and the experimental design and evaluation methods are explained. Next, in Section 3, the change of mean temperature, a few climate indices, and the UHI are studied in SURFEX, and the temperature and climate indices are compared to ALADIN as well. Also in this Section, a simple method is presented to produce detailed future temperature fields that are free from systematic biases. Finally, our conclusions and future plans are given in Section 4. 


\section{Data and methods}

\subsection{The SURFEX land surface model}

In the present study the 5.1 version of the SURFEX (Masson et al., 2013) multilayer land surface model is used in offline mode. This set-up allows to obtain much higher resolution at low computing costs compared to the online coupling, since the computation is realized in one dimension (vertically, for each gridcell separately), therefore, the stability criterions for waves and advection are irrelevant. SURFEX is responsible for simulating the land surface processes in the constant flux layer of the planetary boundary layer, called surface layer. Four different surfaces (natural land, inland water, sea, and town) can be differentiated by the model, with dedicated schemes applied for each of them. The model can be used for a wide variety of horizontal resolutions (from the order of $100 \mathrm{~m}$ to the order of $100 \mathrm{~km}$ resolution) in a way, that the subgrid-scale surface heterogeneity is handled by the tiling method (Avissar and Pielke, 1989). The land cover information is provided for SURFEX by the 1st version of the ECOCLIMAP database (Masson et al., 2003) that reflects the land use, land cover characteristics of the 90s. Among the four surface types, the town and natural land surfaces are the most relevant from the perspective of Budapest, therefore, the corresponding schemes are presented hereinafter.

Over natural land surfaces, the ISBA-3L (Interaction Soil Biosphere Atmosphere model with 3 layers; Boone et al., 1999) scheme is used, that computes the surface and soil temperature and moisture with the force-restore method (Noilhan and Planton, 1989).

The urban physical properties are calculated with the TEB (Town Energy Balance) scheme (Masson; 2000) that follows the canyon concept. The surface conditions of roof, wall, and road are treated separately with prognostic equations; moreover, the surfaces are divided into three layers in order to take heat conductivity into account. Only domestic heating is considered in our model setup as anthropogenic heat source, by preventing indoor temperature to fall below $19{ }^{\circ} \mathrm{C}$. The near surface variables (e.g., $2 \mathrm{~m}$ temperature, humidity, $10 \mathrm{~m}$ wind speed) are calculated with the Surface Boundary Layer (SBL) scheme (Hamdi and Masson, 2008; Masson and Seity, 2009).

\subsection{The driving RCM: HMS-ALADIN5.2}

The atmospheric forcings of the SURFEX are temperature, humidity, wind speed, and wind direction at a few tenth of $\mathrm{m}$ above ground level, downward shortwave and longwave radiation, surface pressure, snow, and rain. In our case, the forcings are provided by the HMS-ALADIN5.2 (Bán et al., 2021) hydrostatic spectral RCM. The physical parameterization package of ALADIN is derived from the ARPEGE-Climat version 5 (Voldoire et al., 2013) atmospheric GCM. The longwave radiation transfer is described by the RRTM (Rapid Radiation Transfer 
Model; Mlawer et al., 1997) scheme, while the shortwave radiation transfer is parameterized according to Fouquart and Bonnel (1980). The large-scale precipitation is determined by the Smith scheme (Smith, 1990), and the convective cloud and precipitation formation are described in Bougeault (1985). The surface scheme of ALADIN is SURFEX version 5, in which ISBA-3L was applied over natural land surfaces. The vertical profiles of temperature, humidity, and wind speed in the surface layer are parameterized according to Geleyn (1988). Urbanized areas are substituted with rocks, and the physical processes are described by the ISBA scheme.

\subsection{Experimental design}

In this study, a century-long urban climate simulation is assessed, performed with the 5.1 version of SURFEX for Budapest driven by the HMS-ALADIN5.2 and using the RCP8.5 scenario, that estimates strong greenhouse gas (GHG) increase throughout the 21 st century. The simulation period of SURFEX was 1960-2100, and the forcings are provided at $30 \mathrm{~m}$ above ground level by the ALADIN, achieved at $10 \mathrm{~km}$ horizontal resolution on a domain covering Central and Southeastern Europe (top panel of Fig. 1) for the period of 1951-2100. The lateral boundary conditions of ALADIN are obtained from the CNRM-CM5 (Centre National de Recherches Météorologiques Coupled global climate Model; Voldoire et al., 2013), that was downscaled in two steps to the $10 \mathrm{~km}$ resolution domain. On the period of 1951-2005, the RCM considered observed greenhousegas concentrations (Meinshausen et al., 2011), while from 2006 to 2100, the concentrations followed the RCP8.5 scenario. RCP8.5 foresees $8.5 \mathrm{~W} / \mathrm{m}^{2}$ global radiative forcing increase by 2100 with respect to the preindustrial level.

The integration domain of SURFEX consists of $61 \times 61$ gridpoints with $1 \mathrm{~km}$ horizontal resolution and covers Budapest and its vicinity (Fig. 1). The ALADIN simulations are interpolated from $10 \mathrm{~km}$ to $1 \mathrm{~km}$ resolution using the 927 configuration of ALADIN (which is responsible for preparing the lateral boundary conditions for the RCM). The integration timestep of SURFEX is 300 $\mathrm{s}$, to which the 3-hour forcings are linearly interpolated. 

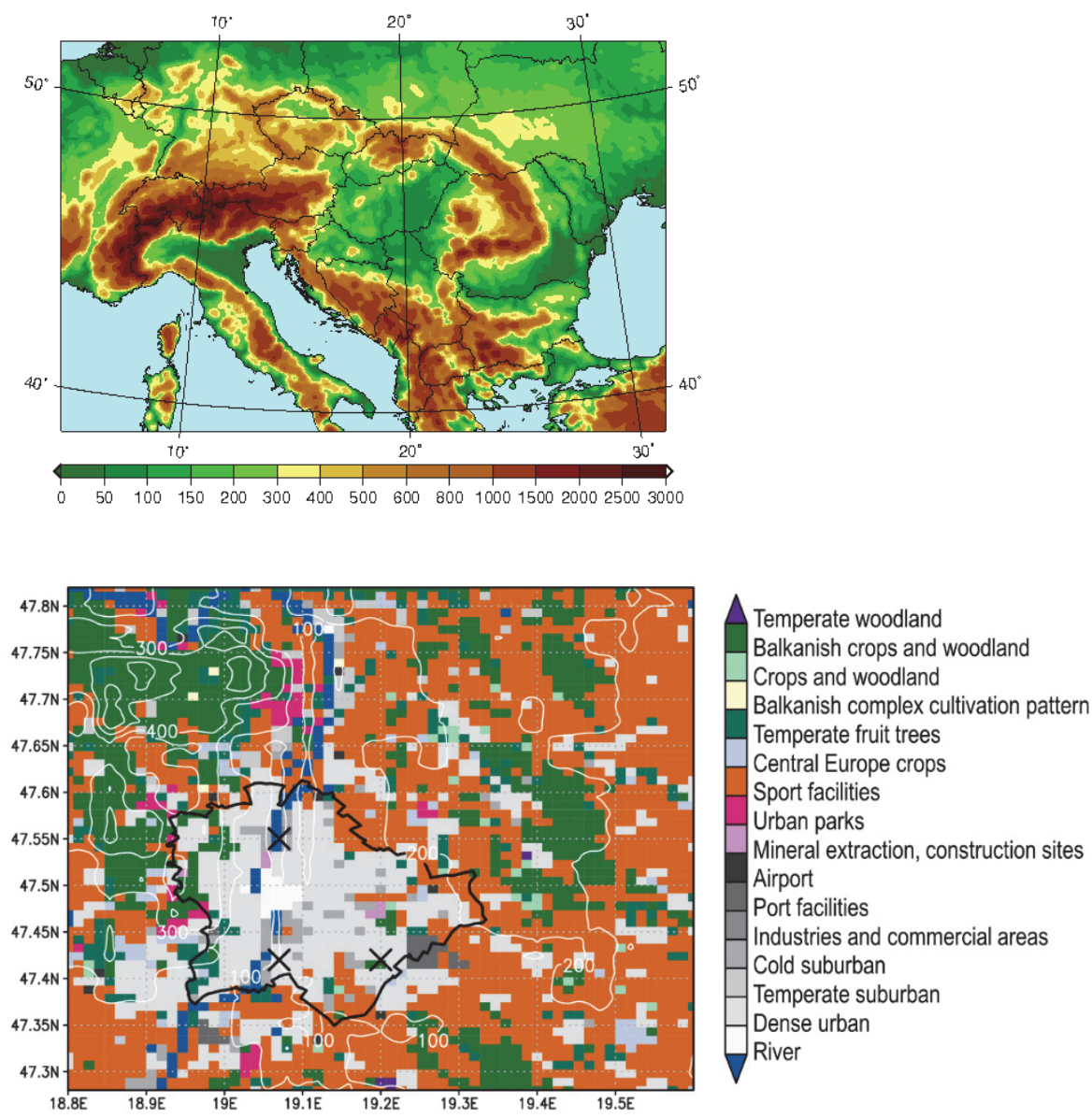

Fig. 1. Top: integration domain and orography (m) of the HMS-ALADIN5.2 regional climate model. Bottom: land cover categories over the SURFEX integration domain according to ECOCLIMAP (colored gridcells) and orography (m; white isolines). The administrative border of Budapest is marked with black line, and the included ALADIN gridpoints are marked with black $\mathrm{x}$.

\subsection{Evaluation methods}

First, the temperature change and the change of four climate indices (heatwave days, tropical nights, frost days, and very cold days, Table 1) are studied and compared in SURFEX and ALADIN on 30-year periods, particularly 2021-2050 and 2071-2100, with respect to 1971-2000. The future change of climate indices are mainly presented in relative form, since in this way, differences between urban and rural areas are better revealed than considering mean changes in days.

Besides considering the climate projections for the entire SURFEX domain, the results over Budapest are scrutinized to assess the future climate change of Budapest according to the RCM and LSM. Therefore, in ALADIN and SURFEX the gridpoints outside of the administrative border of the city were masked out. Note that in the case of ALADIN, only 3 gridpoints fall over the area of Budapest (see Fig. 1). 
In addition to the change of temperature and climate indices, the future evolution of UHI intensity was also studied in SURFEX. The UHI intensity was computed as the following: in every timestep and every gridpoint the $2 \mathrm{~m}$ temperature value was subtracted from the mean rural temperature, which latter was determined as the average temperature of pure rural grid cells.

Table 1. Name and definition of presented climate indices

\begin{tabular}{lc}
\hline \hline Name of climate indices & Definition \\
\hline \hline Heatwave days & daily mean temperature $\geq 25^{\circ} \mathrm{C}$ \\
Tropical nights & daily minimum temperature $>20^{\circ} \mathrm{C}$ \\
Frost days & daily minimum temperature $<0{ }^{\circ} \mathrm{C}$ \\
Very cold days & daily minimum temperature $<-10{ }^{\circ} \mathrm{C}$ \\
\hline
\end{tabular}

Finally, a simple bias adjustment method is applied in order to investigate the expected mean future temperatures of Budapest, compared to its natural environment. The adjustment was performed for the 30-year mean temperature of ALADIN, using the $10 \mathrm{~km}$ resolution CARPATCLIM-HU gridded observation dataset (Bihari et al., 2017) as reference. CARPATCLIM-HU was constructed based on homogenized and interpolated station measurements according to the MASH (Szentimrey, 2008) and MISH (Szentimrey and Bihari, 2007) methods, and widely used for regional climate model evaluation for Hungary. In the next step, the UHI intensity field of SURFEX is added to the bias adjusted ALADIN according to the following equation:

$$
\bar{T}_{c o r r}=\left(\bar{T}_{R C M, f}-\bar{T}_{R C M, p}\right)+\bar{T}_{o b s, p}+U H I_{f},
$$

where $\bar{T}_{R C M, f}$ and $\bar{T}_{R C M, p}$ stand for the future and past 30-year area means of ALADIN, $\bar{T}_{o b s, p}$ refers for the past 30-year area mean of CARPATCLIM-HU, while $U H I_{f}$ means the future 30-year mean UHI field. 


\section{Results and discussion}

\subsection{Change of temperature and extreme events}

First, the $2 \mathrm{~m}$ temperature change over Budapest is investigated in SURFEX and compared with the $10 \mathrm{~km}$ resolution ALADIN projections. The most warming season according to SURFEX is winter with $1.9^{\circ} \mathrm{C}$ in $2021-2050$ and $4.3{ }^{\circ} \mathrm{C}$ in 2071-2100, while the smallest temperature change is expected in spring (Fig. 2, Table 2). Looking at the seasonal warming trend in the ALADIN, it is clear that the LSM projects lower temperature change than the RCM in all seasons except autumn (Fig. 3, Table 2). The largest difference $\left(0.5-0.6^{\circ} \mathrm{C}\right)$ is obtained in spring and summer in both future periods, and in winter in 2071-2100. In addition, it is mentioned that this departure is increasing in the beginning of the 21 st century (until 2030-2040), then it remains nearly constant except winter, when this process continues until 2060s. Since the abovementioned findings are valid over the whole domain as well (not shown), this behavior is rather attributed to the LSM itself and not limited to the TEB scheme over the urbanized areas.
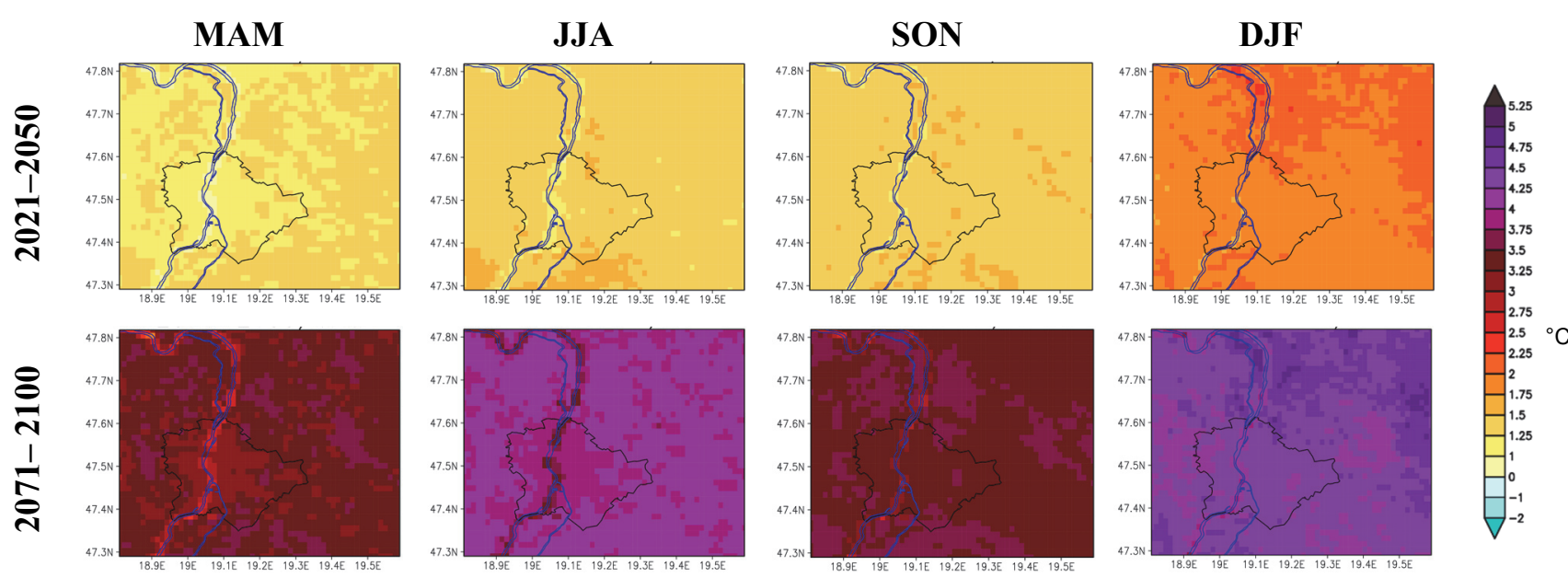

Fig. 2. Seasonal mean temperature change $\left({ }^{\circ} \mathrm{C}\right)$ in $2021-2050$ and $2071-2100$ simulated by SURFEX. Reference: 1971-2000.

Table 2. Annual and seasonal mean temperature change $\left({ }^{\circ} \mathrm{C}\right)$ in $2021-2050$ and $2071-2100$ simulated by ALADIN and SURFEX over Budapest. Reference: 1971-2000

\begin{tabular}{ccccccc}
\hline \hline & & Annual & MAM & JJA & SON & DJF \\
\hline \hline \multirow{2}{*}{ ALADIN } & $\mathbf{2 0 2 1 - 2 0 5 0}$ & 1.7 & 1.5 & 1.7 & 1.5 & 2.2 \\
& $\mathbf{2 0 7 1 - 2 1 0 0}$ & 4.1 & 3.7 & 4.4 & 3.6 & 4.8 \\
& & & & & & \\
\multirow{2}{*}{ SURFEX } & $\mathbf{2 0 2 1 - 2 0 5 0}$ & 1.5 & 1.1 & 1.3 & 1.4 & 1.9 \\
& $\mathbf{2 0 7 1 - 2 1 0 0}$ & 3.7 & 3.2 & 3.9 & 3.4 & 4.3 \\
\hline
\end{tabular}



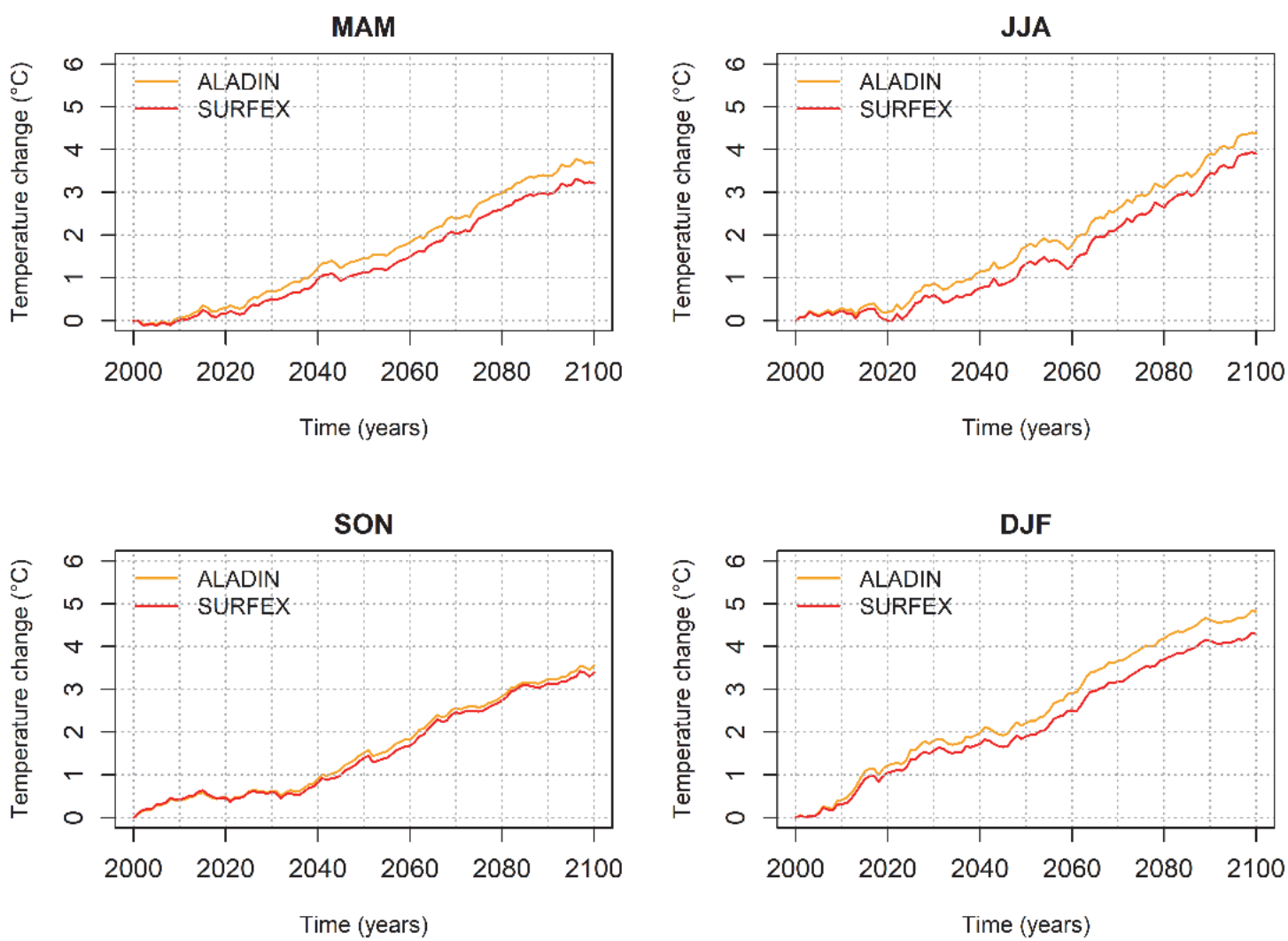

Fig. 3. Seasonal temperature change $\left({ }^{\circ} \mathrm{C}\right)$ in SURFEX and ALADIN between 2000 and 2100 averaged over Budapest. The year-to-year variability is smoothed with 30 -year running average (in each year the precedent 30-year mean is indicated). Reference: 1971-2000.

Regarding the spatial distribution of temperature change in SURFEX, the city and its rural vicinity portrays similar warming tendency, except in spring and summer by the end of the century, when the temperature increase is $0.25^{\circ} \mathrm{C}$ less in Budapest, compared to the other parts of the domain (Fig. 2). Similar pattern is seen only in the minimum temperature change fields, the maximum temperature change does not affected significantly by the land cover type (not shown).

The future change of climate indices portrays different relationship between the projected values in ALADIN and SURFEX in some cases, compared to the conclusions based on the mean temperature changes. While ALADIN indicates larger relative changes of heatwave days and tropical nights with respect to SURFEX, which is especially notable for tropical nights (the difference between the two models is $66 \%$ and $207 \%$ in $2021-2050$ and $2071-2100$, respectively); the indices, representing low temperatures, decrease to a greater extent in SURFEX. Although it is noted that the change expressed in days is always larger in ALADIN, i.e., SURFEX projects 1-3 days less heatwave days and tropical nights in both future periods, 10 days less frost days in 2071-2100, and 6-9 days less very cold days in the near and far future, respectively. The controversies for low temperature indices can be explained by that they are less frequent in 
SURFEX than in ALADIN in the reference period (with 34 days for frost days and with 9 days for very cold days; Table 3) partly due to the warming effect of the city, while the projected future changes in the two models are less different.

Considering the spatial distribution of the relative change of climate indices in SURFEX, the downtown of Budapest (that is a small central area on the right side of the Danube) may encounter larger relative decrease of frost days (in 2021$205030-35 \%$, in $2071-2100$ more than $70 \%$ reduction is projected) than in the outer districts or in the rural areas of the domain (Fig. 4). In contrast, the heatwave days change the least in the downtown and in Budapest compared to the other parts of the domain.

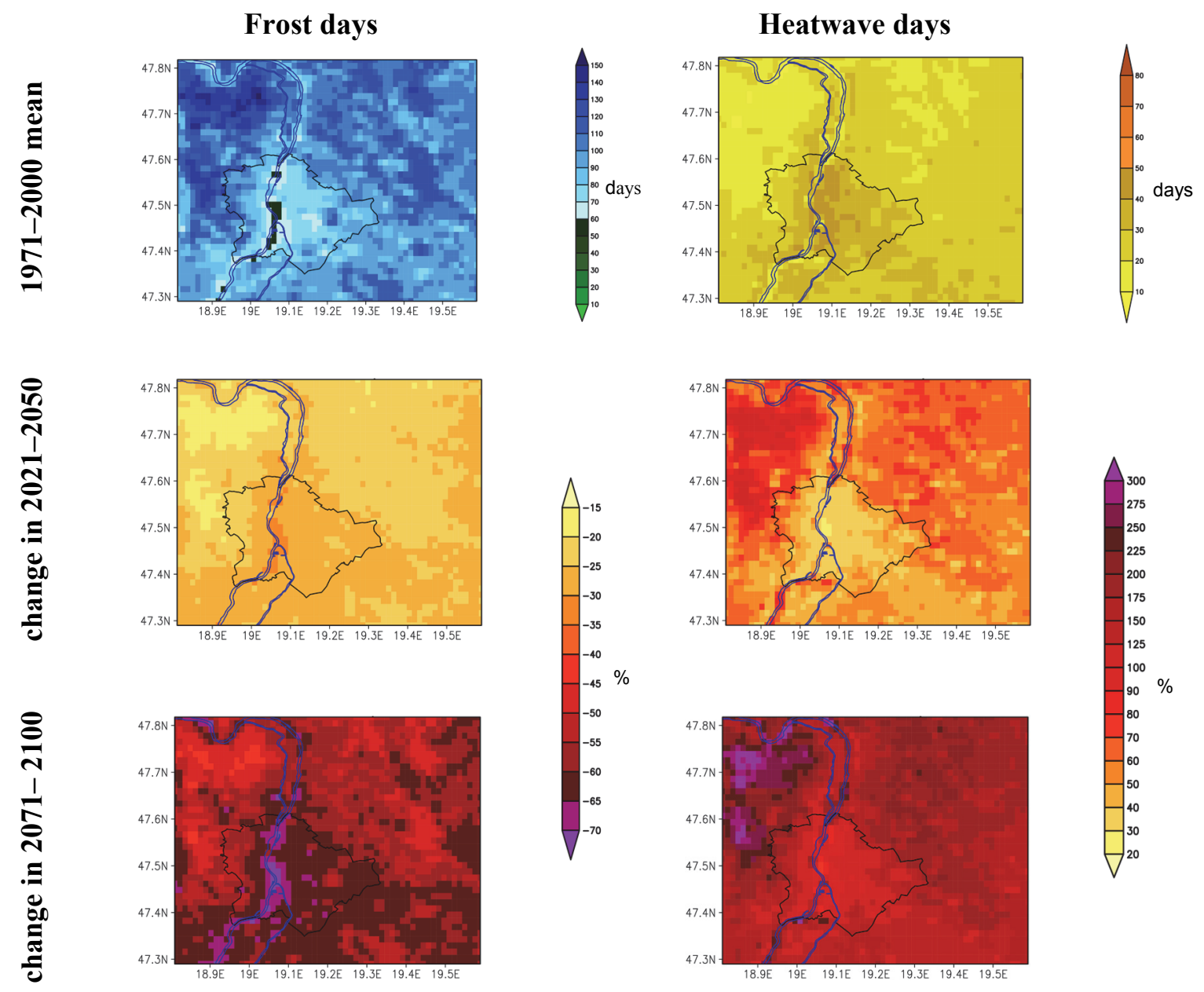

Fig. 4. Average number of frost days and heatwave days in SURFEX in 1971-2000 and their relative changes (\%) in 2021-2050 and 2071-2100, with respect to 1971-2000. 
Table 3. Average number of climate indices in 1971-2000 (first row) and their mean and relative changes (days and \%, respectively) in 2021-2050 and 2071-2100 (second and third rows) over Budapest simulated by ALADIN and SURFEX, with respect to 1971-2000

\begin{tabular}{|c|c|c|c|c|c|c|c|c|c|}
\hline & \multirow[b]{2}{*}{ unit } & \multicolumn{2}{|c|}{ Heat wave days } & \multicolumn{2}{|c|}{ Tropical nights } & \multicolumn{2}{|c|}{ Frost days } & \multicolumn{2}{|c|}{ Very cold days } \\
\hline & & ALADIN & SURFEX & ALADIN & SURFEX & ALADIN & SURFEX & ALADIN & SURFEX \\
\hline $\begin{array}{c}\text { 1971-2000 } \\
\text { means }\end{array}$ & days & 28 & 33 & 13 & 33 & 118 & 84 & 15 & 6 \\
\hline \multirow{2}{*}{$\begin{array}{l}\text { change in } \\
2021-2050\end{array}$} & $\%$ & 59 & 43 & 126 & 60 & -21 & -27 & -73 & -82 \\
\hline & days & (17) & (14) & (16) & (17) & $(-25)$ & $(-22)$ & $(-11)$ & $(-5)$ \\
\hline \multirow{2}{*}{$\begin{array}{l}\text { change in } \\
2071-2100\end{array}$} & $\%$ & 148 & 127 & 374 & 167 & -51 & -62 & -98 & -100 \\
\hline & days & (42) & $(40)$ & $(48)$ & (47) & $(-61)$ & $(-51)$ & $(-15)$ & $(-6)$ \\
\hline
\end{tabular}

\subsection{Change of UHI}

The decrease of UHI intensity at 0 UTC is projected by SURFEX in each season for both future periods (Fig. 5 and Table 4). Spring and summer may reckon with the largest change, i.e., -0.27 and $-0.22{ }^{\circ} \mathrm{C}$ in $2021-2050$ and -0.35 and $-0.32{ }^{\circ} \mathrm{C}$ in 2071-2100, respectively. Note that these seasons are characterized by the largest UHI in the past (2.0 in spring and $2.1^{\circ} \mathrm{C}$ in summer). In contrast, in autumn and winter, the UHI intensity drop does not exceed $0.2{ }^{\circ} \mathrm{C}$ in each future period, and there is no substantial difference between the urban and rural gridpoints. The projected negative tendencies seem to significantly reduce in the second half of the century, since the decrease between 2021-2050 and 1971-2000 is much larger than between the two future periods. Note that ALADIN (the driving model of SURFEX) projects $10-30 \%$ wetter future conditions for Hungary throughout the year for the entire 21 st century in conjunction with a strong temperature increase (Bán et al., 2021). However, this does not have straightforward impact on the soil conditions. In summer, the soil moisture (of the middle layer) is reduced by up to $5 \%$ at the end of the century over the SURFEX domain (Fig. 6). In spring and autumn, after a few $\%$ of increase in the first half of the century, the soil moisture returns to the conditions of the reference period, while it increases heavily in winter. A continuous increase is seen in the soil temperature (also of the middle layer) in every seasons, most intensively in spring, although, the largest $2 \mathrm{~m}$ temperature was obtained in winter. All this suggests that the more precipitation in ALADIN cannot prevent the summer soil moisture loss in the future, and the strong soil temperature increase in spring and summer (while the surface properties of the paved and built-up areas in the city remain invariant) may explain 
the larger nocturnal UHI reduction in these seasons. Hamdi et al. (2014) and Chapman et al. (2019) found similar results in terms of future reduction of the nocturnal UHI intensity for Brussels, Paris, and Brisbane, and also explained the stronger drying of natural land surfaces around the city by soil moisture reduction.

Table 4. Seasonal mean nocturnal UHI intensity (at $0 \mathrm{UTC} ;{ }^{\circ} \mathrm{C}$ ) in Budapest simulated by SURFEX in 1971-2000 (first row), and its mean changes $\left({ }^{\circ} \mathrm{C}\right)$ in 2021-2050 and 20712100 , with respect to $1971-2000$ (second and third rows)

\begin{tabular}{ccccc}
\hline \hline & MAM & JJA & SON & DJF \\
\hline \hline 1971-2000 means & 2.0 & 2.1 & 1.8 & 1.4 \\
\hline change in 2021-2050 & -0.27 & -0.22 & -0.14 & -0.13 \\
change in 2071-2100 & -0.35 & -0.32 & -0.16 & -0.14 \\
\hline
\end{tabular}
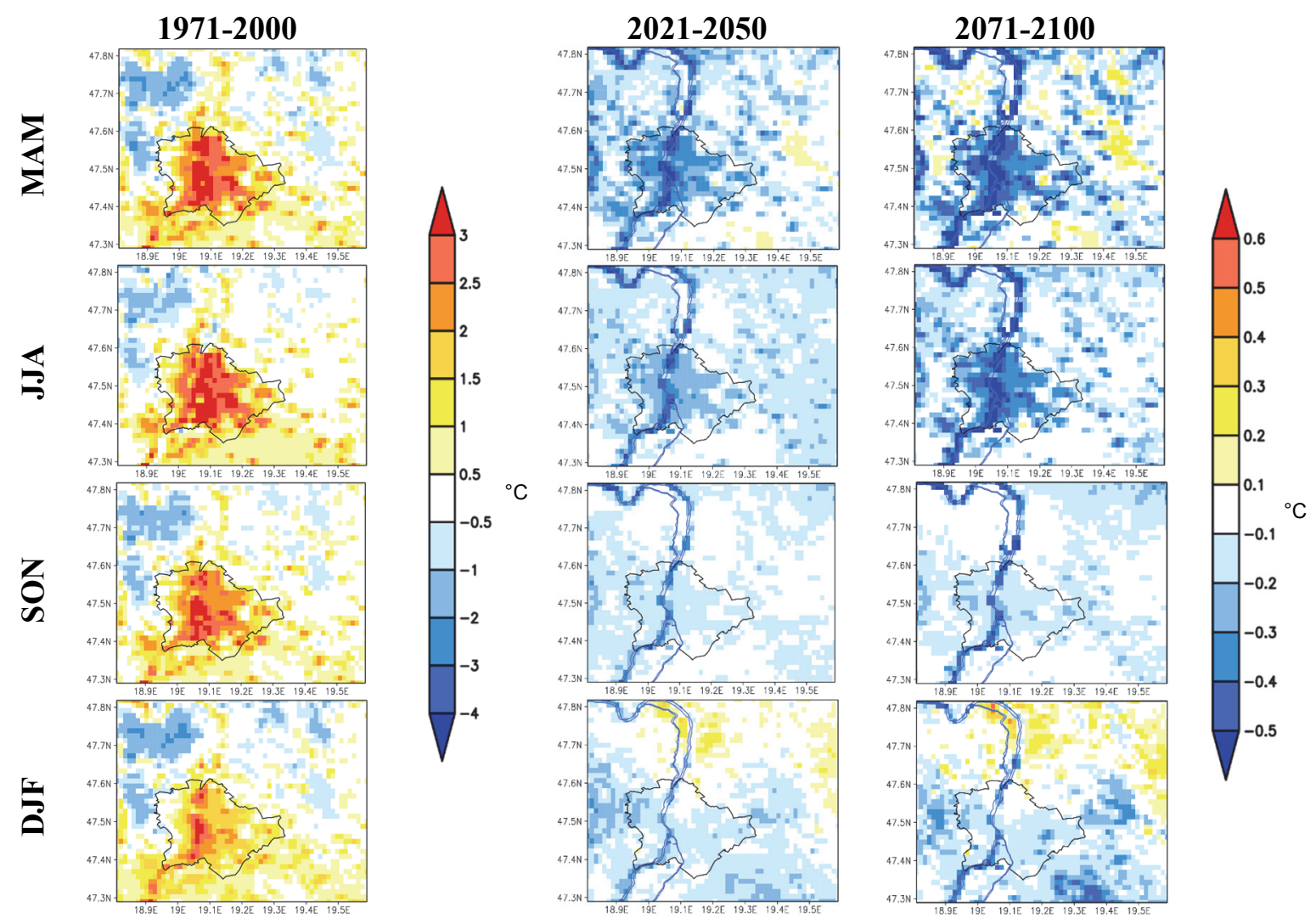

Fig. 5. First column: seasonal mean nocturnal UHI intensity (at $0 \mathrm{UTC} ;{ }^{\circ} \mathrm{C}$ ) simulated by SURFEX in 1971-2000. Second and third column: change $\left({ }^{\circ} \mathrm{C}\right)$ of mean nocturnal UHI intensity in 2021-2050 and 2071-2100, respectively; reference: 1971-2000. 

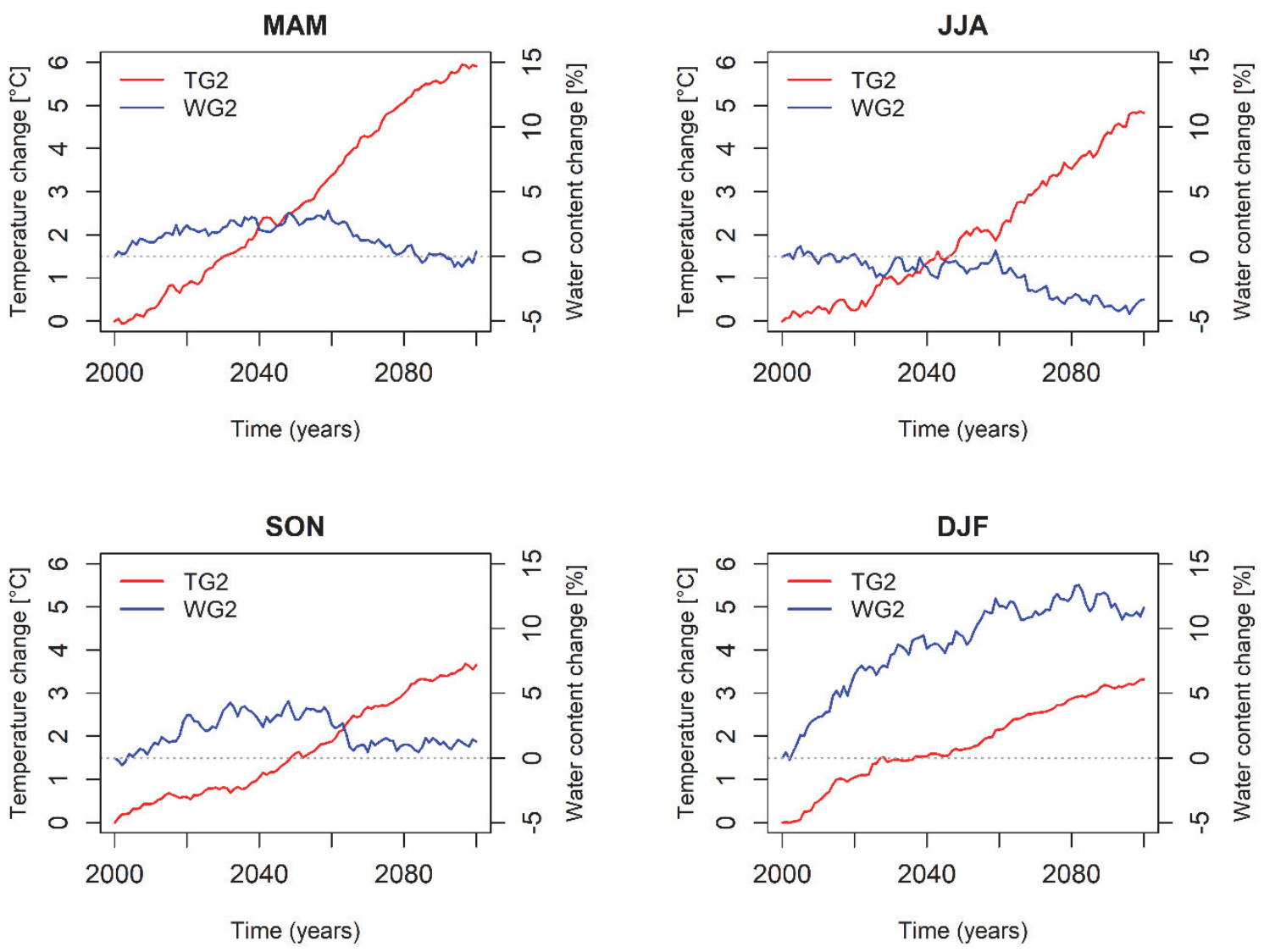

Fig. 6. Seasonal mean soil moisture (WG2) and soil temperature (TG2) change (in \% and in ${ }^{\circ} \mathrm{C}$, respectively) between 2000 and 2100 in the middle soil layer of SURFEX averaged over the model domain. The year-to-year variability is smoothed with 30-year running average (in each year the precedent 30-year mean is indicated). Reference: 1971-2000.

\subsection{Bias adjustment of mean temperature of SURFEX}

In the previous sections it was shown, that the high temperature extremes may change at a smaller rate inside the city than in the outskirt regions, and the UHI intensity may reduce in the future. Despite these results indicate the modification of the urban-rural contrast in terms of temperature and temperature indices, this change is much smaller than the contrast itself. Therefore, the fact that the urbanized areas are especially exposed to certain aspects of climate change is partly hidden in the results presented by the classical way developed in the climate model community, i.e., considering mean changes. All these suggest that the (bias adjusted) future means provided by the model may provide more actionable and visionable information for the users interested in urban climate.

All bias adjustment methods require long, quality observations, suitable for the target needs. From urban climate perspectives, to correct a $\mathrm{km}$-scale land surface model, a $\mathrm{km}$-scale gridded reference dataset based on station 
measurements, that comprises urban signature is needed. In Budapest, from the beginning of the 2000s, four urban stations are operating, although most of them are not included in the $10 \mathrm{~km}$ resolution CARPATCLIM-HU. Therefore, even if it is interpolated to $1 \mathrm{~km}$ resolution, the detailed urban effect would be missing due to the lack of long urban measurements. Therefore, using this reference to directly bias-correct the SURFEX outputs would eliminate the urban pattern from the model. In the following, a simple method is given to provide future means of SURFEX that are cleaned from systematic biases.

Since the benefit of SURFEX is that it can simulate the urban effect compared to ALADIN, the idea is to bias adjust the $10 \mathrm{~km}$ resolution area means of ALADIN using the CARPATCLIM-HU and adding the "urban effect" field to this value. E.g., in the case of temperature, this urban effect is the UHI, since it shows how different the temperature is over the city compared to the environment (that can be simulated by ALADIN). Fig. 7 shows the mean seasonal temperature of SURFEX in 2021-2050 and 2071-2100. Based on this method, the mean temperature in Budapest can be $22-23$ and $25{ }^{\circ} \mathrm{C}$ in summer, and $5-6$ and $6-7{ }^{\circ} \mathrm{C}$ in winter, in 2021-2050 and 2071-2100, respectively, which are approximately $2{ }^{\circ} \mathrm{C}$ warmer than the natural surfaces in the outskirts.

It must be mentioned, that this method should be considered as a first approximation to bias-adjust SURFEX and can be improved several ways. First, Budapest is situated in a complex orography area, surrounded by mountains, and for the mean rural temperature computation, we considered all rural gridpoints regardless of their elevation. However, especially the Buda Hills have a cooling effect on the rural temperature, that may result exaggerated UHI intensity. The UHI intensity must be especially well defined, when it may affect the outcome of the impact studies.

Moreover, in this method only the RCM is corrected, but the inaccuracies of urban pattern (i.e., the intensity and spatial distribution of UHI) were kept unchanged due to the lack of a high-resolution urban station network.

Finally, it must be also bear in mind, that no urban development scenario (i.e., land cover change) was taken into account in this century-long simulation, therefore, only the impact of altered climate conditions was assessed on the present conditions of Budapest. However, Chapman et al. (2019) showed that considering urban growth and climate change hand in hand, the negative effects of climate change (e.g., number of hot nights, dangerous heat stress) were amplified compared to ignoring the change of city structure. Lemonsu et al. (2015) studied several urban expansion and structural change scenarios and found that urban densification increases UHI especially at night, while implementing green areas in the city center led to reduced nocturnal UHI, but amplified daytime values. 

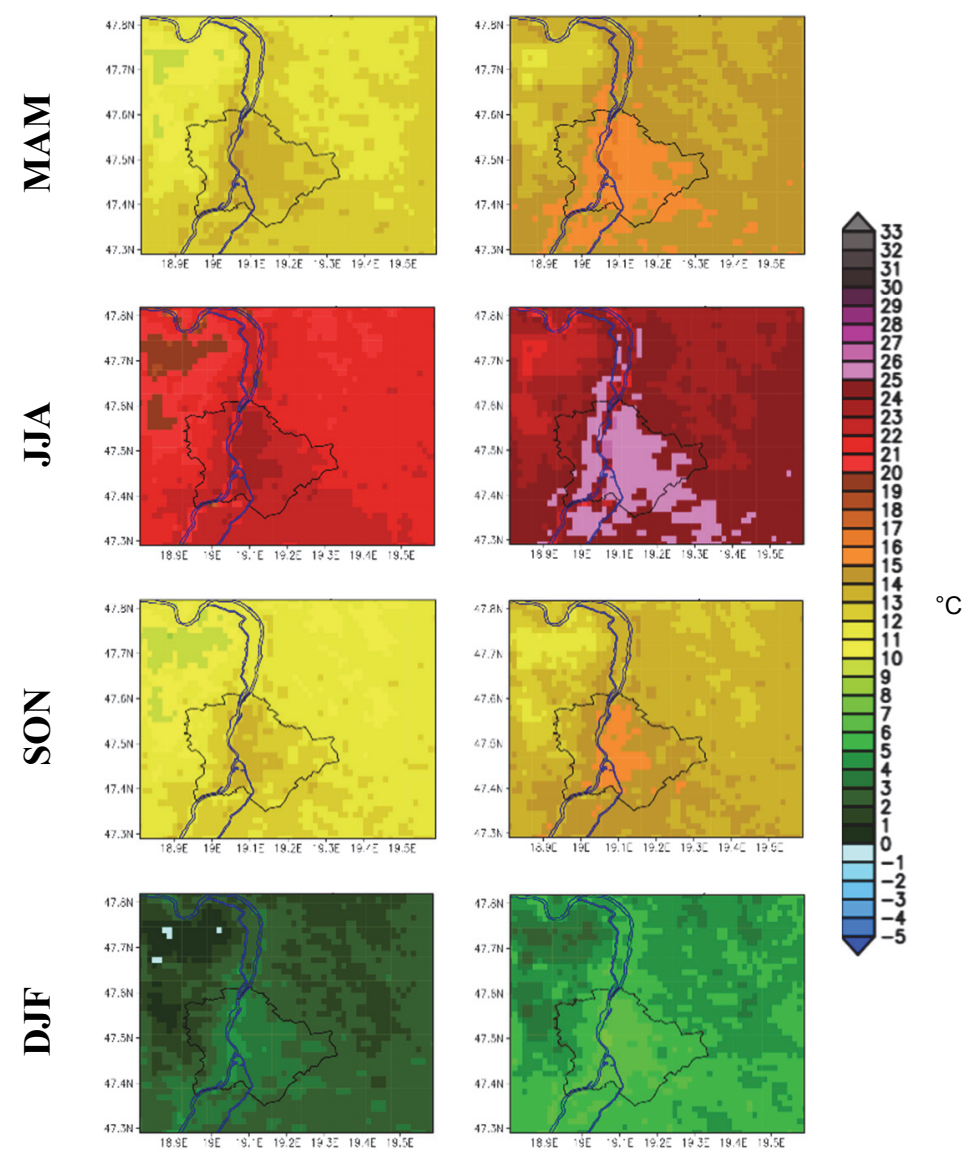

Fig. 7. Seasonal mean bias-adjusted $2 \mathrm{~m}$ temperature $\left({ }^{\circ} \mathrm{C}\right)$ in $2021-2050$ and $2071-2100$ according to the SURFEX.

\section{Conclusions}

In this paper, the first results of future temperature and UHI changes of Budapest achieved by the ALADIN driven SURFEX land surface model are presented. Besides the analysis of the $1 \mathrm{~km}$ resolution SURFEX, the scope of the paper was to investigate how different the simulated urban climate is from the $10 \mathrm{~km}$ resolution RCM results, that considers urban processes with a simple bulk scheme (i.e., the urbanized surfaces are represented by rocks).

The largest temperature change over Budapest is expected in winter $\left(1.9^{\circ} \mathrm{C}\right.$ and $4.3^{\circ} \mathrm{C}$ in 2021-2050 and 2071-2100), that is in line with the ALADIN results for Hungary (Bán et al., 2021). Except for autumn, SURFEX clearly projects more moderate temperature change compared to its driving model, especially in spring and summer. This discrepancy may be explained by that the set-up of SURFEX slightly differs to the one built-in ALADIN, and that the LSM does not model the full atmosphere. 
Heatwave days and tropical nights may increase in the city with $43 \%$ and $60 \%$ in 2021-2050, while they may at least double at the end of the century. Only low temperature indices are projected to larger decrease in SURFEX compared to ALADIN and in the downtown compared to the suburbs and rural areas.

According to SURFEX, the nocturnal UHI in Budapest may be less intense in the future, to the most in spring and summer, when the model gave the strongest UHI in the past. This natural UHI mitigation may be explained by that the soil in the rural areas dry out in the future, therefore, these areas warm at a higher rate compared to the city. These findings reassure, that the relationship between the urban and rural areas may change in the future due to altered physical processes, which can properly be simulated only with dynamical models.

Finally, an attempt to bias-adjust the SURFEX temperature fields were given using the delta method on ALADIN mean temperature, superimposed by the UHI field derived from SURFEX. The bias-adjusted future results of SURFEX reveal that more extreme conditions are expected in the city, this information may be hidden by considering mean changes.

However, it must be emphasized, that in order to adequately estimate the future climate change in cities, more simulations are needed, driven by different scenarios and models. This need drives our future plans, to conduct century-long simulations with SURFEX with the RCP4.5 scenario and to couple SURFEX to the REMO regional climate model, also adapted at the HMS.

Acknowledgment: The research was funded by the Environmental and Energy Efficiency Operative Program (KEHOP; grant number: KEHOP-1.1.0-15-2015-00001). ALADIN-Climate simulation was performed within the framework of the RCMGiS (EEA-C13-10) project.

\section{References}

Avissar, R. and Pielke, R.A., 1989: A Parameterization of Heterogeneous Land Surfaces for Atmospheric Numerical Models and Its Impact on Regional Meteorology. Month. Weather Rev. 117, 2113https://doi.org/10.1175/1520-0493(1989)117<2113:APOHLS $>2.0 . C O ; 2$

Bassett, R., Young, P.J., Blair, G.S., Cai, X.-M., and Chapman, L., 2020: Urbanisation's contribution to climate warming in Great Britain. Environ. Res. Lett. 15, 114014. https://doi.org/10.1088/1748-9326/abbb51

Bán, B., Szépszó, G., Allaga-Zsebeházi, G., and Somot, S., 2021: ALADIN-Climate at the Hungarian Meteorological Service: from the beginnings to the present day's results, Idojjárás 125, 647-673. https://doi.org/10.28974/idojaras.2021.4.6

Bihari, Z., Lakatos, M., and Szentimrey, T., 2017: Felszíni megfigyelésekböl készített rácsponti adatbázisok az Országos Meteorológiai Szolgálatnál. Légkör 62, 148-151. (in Hungarian)

Boone, A., Calvet, J.-C., and Noilhan, J., 1999: Inclusion of a Third Soil Layer in a Land Surface Scheme Using the Force-Restore Method. J. Appl. Meteorol. 38, 1611-1630.

https://doi.org/10.1175/1520-0450(1999)038<1611:IOATSL $>2.0 . C O ; 2$

Bougeault, $P$., 1985: A simple parameterization of the large-scale effects of cumulus convection. Month. Weather Rev. 113, 2108-2121.

https://doi.org/10.1175/1520-0493(1985)113<2108:ASPOTL>2.0.CO;2 
Chapman, S., Thatcher, M., Salazar, A., Watson, J.E.M., and McAlpine, C.A., 2019: The impact of climate change and urban growth on urban climate and heat stress in a subtropical city. Int. $J$. Climatol. 39, 3013-3030. https://doi.org/10.1002/joc.5998

Dian, Cs., Pongrácz, R., Dezsö, Zs., and Bartholy, J., 2020: Annual and monthly analysis of surface urban heat island intensity with respect to the local climate zones in Budapest. Urban Climate, 31, 100573. https://doi.org/10.1016/j.uclim.2019.100573

Ehret, U., Zehe, E., Wulfmeyer, V., Warrach-Sagi, K., and Liebert, J., 2012: HESS Opinions 'Should we apply bias correction to global and regional climate model data?' Hydrol. Earth Syst. Sci. 16, 3391-3404. https://doi.org/10.5194/hess-16-3391-2012

Fouquart, Y. and Bonnel, B., 1980: Computation of solar heating of the Earth's atmosphere: A new parameteizatio. Beitr. Phys. Atmos. 53, 35-62.

Geleyn, J.-F., 1988: Interpolation of wind, temperature and humidity values from model levels to the height of measurement. Tellus A 40, 347-351.

https://doi.org/10.1111/j.1600-0870.1988.tb00352.x

Hamdi, R. and Masson, V., 2008: Inclusion of a Drag Approach in the Town Energy Balance (TEB) Scheme: Offline 1D Evaluation in a Street Canyon. J. Appl. Meteorol. Climatol. 47, 2627-2644. https://doi.org/10.1175/2008JAMC1865.1

Hamdi, R., Van de Vyver, H., De Troch, R., and Termonia, P., 2014: Assessment of three dynamical urban climate downscaling methods: Brussels's future urban heat island under an A1B emission scenario: BRUSSELS'S FUTURE URBAN HEAT ISLAND. Int. J. Climatol. 34, 978-999. https://doi.org/10.1002/joc.3734

Lakatos, M. and Bihari, Z., 2011: A közelmúlt megfigyelt hőmérsékleti- és csapadéktendenciái. In (eds.: Bartholy, J., Bozó, L., Haszpra, L.: Klímaváltozás - 2011: Klímaszcenáriók a Kárpát-medence térségére Hungarian Academy of Sciences and Meteorological Department of ELU, Budapest, 146-169.

Langendijk, G.S., Rechid, D., and Jacob, D., 2019: Urban Areas and Urban-Rural Contrasts under Climate Change: What Does the EURO-CORDEX Ensemble Tell Us?-Investigating near Surface Humidity in Berlin and Its Surroundings. Atmosphere 10, 730. https://doi.org/10.3390/atmos 10120730

Lauwaet, D., De Ridder, K., Saeed, S., Brisson, E., Chatterjee, F., van Lipzig, N.P.M., Maiheu, B., and Hooyberghs, H., 2016: Assessing the current and future urban heat island of Brussels. Urban Climate 15, 1-15. https://doi.org/10.1016/j.uclim.2015.11.008

Lemonsu, A., Viguié, V., Daniel, M., and Masson, V., 2015: Vulnerability to heat waves: Impact of urban expansion scenarios on urban heat island and heat stress in Paris (France). Urban Climate 14, Part 4, 586-605. https://doi.org/10.1016/j.uclim.2015.10.007

Lo, Y.T.E., Mitchell, D.M., Bohnenstengel, S.I., Collins, M., Hawkins, E., Hegerl, G.C., Joshi, M., and Stott, P.A., 2020: U.K. Climate Projections: Summer Daytime and Nighttime Urban Heat Island Changes in England's Major Cities. J. Climate 33, 9015-9030. https://doi.org/10.1175/JCLI-D-19-0961.1

Masson, V., Champeaux, J.-L., Chauvin, F., Meriguet, C., and Lacaze, R., 2003: A Global Database of Land Surface Parameters at 1-km Resolution in Meteorological and Climate Models. J. Climate 16, 1261-1282. https://doi.org/10.1175/1520-0442(2003)16<1261:AGDOLS >2.0.CO;2

Masson, $V$. and Seity, Y., 2009: Including Atmospheric Layers in Vegetation and Urban Offline Surface Schemes. J. Appl. Meteorol. Climatol. 48, 1377-1397. https://doi.org/10.1175/2009JAMC1866.1

Masson, V., Le Moigne, P., Martin, E., Faroux, S., Alias, A., Alkama, R., Belamari, S., Barbu, A., Boone, A., Bouyssel, F., Brousseau, P., Brun, E., Calvet, J.-C., Carrer, D., Decharme, B., Delire, C., Donier, S., Essaouini, K., Gibelin, A.-L., Giordani, H., Habets, F., Jidane, M., Kerdraon, G., Kourzeneva, E., Lafaysse, M., Lafont, S., Lebeaupin Brossier, C., Lemonsu, A., Mahfouf, J.-F., Marguinaud, P., Mokhtari, M., Morin, S., Pigeon, G., Salgado, R., Seity, Y., Taillefer, F., Tanguy, G., Tulet, P., Vincendon, B., Vionnet, V., and Voldoire, A., 2013: The SURFEXv7.2 land and ocean surface platform for coupled or offline simulation of earth surface variables and fluxes. Geosci. Model Develop. 6, 929-960. https://doi.org/10.5194/gmd-6-929-2013

Masson, V., 2000: A Physically-Based Scheme For The Urban Energy Budget In Atmospheric Models. Bound.-Lay. Meteorol. 94, 357-397. https://doi.org/10.1023/A:1002463829265 
Meinshausen, M., Smith, S.J., Calvin, K., Daniel, J.S., Kainuma, M.L.T., Lamarque, J.-F., Matsumoto, K., Montzka, S.A., Raper, S.C.B., Riahi, K., Thomson, A., Velders, G.J.M., and van Vuuren, D.P.P., 2011: The RCP greenhouse gas concentrations and their extensions from 1765 to 2300. Climatic Change 109, 213. https://doi.org/10.1007/s10584-011-0156-z

Mlawer, E.J., Taubman, S.J., Brown, P.D., Iacono, M.J., and Clough, S.A., 1997: Radiative transfer for inhomogeneous atmospheres: RRTM, a validated correlated-k model for the longwave. $J$. Geophys. Res.: Atmosph. 102, 16663-16682. https://doi.org/10.1029/97JD00237

Noilhan, J. and Planton, S., 1989: A Simple Parameterization of Land Surface Processes for Meteorological Models. Month. Weather Rev. 117, 536-549. https://doi.org/10.1175/1520-0493(1989)117<0536:ASPOLS $>2.0 . C O ; 2$

Oke, T.R., 1982: The energetic basis of the urban heat island. Quart. J. Roy. Meteorol. Soc. 108, 1-24. https://doi.org/10.1002/qj.49710845502

Revi, A., Satterthwaite, D.E., Aragón-Durand,F., Corfee-Morlot, J., Kiunsi,R.B.R., Pelling,M., Roberts, D.C., and Solecki, W., 2014: Urban areas. In (eds.: Field, C.B., Barros, V.R., Dokken, D.J., Mach, K.J., Mastrandrea, M.D., Bilir, T.E., Chatterjee, M., Ebi, K.L., Estrada, Y.O., Genova, R.C., Girma, B., Kissel, E.S., Levy, A.N., MacCracken, S., Mastrandrea, P.R., White, L.L ) Climate Change 2014: Impacts, Adaptation, and Vulnerability. Part A: Global and Sectoral Aspects. Contribution of Working Group II to the Fifth Assessment Report of the Intergovernmental Panel on Climate Change Cambridge University Press, Cambridge, United Kingdom and New York, NY, USA, 535-612.

Riahi, K., Rao, S., Krey, V., Cho, C., Chirkov, V., Fischer, G., Kindermann, G., Nakicenovic, N., and Rafaj, P., 2011: RCP 8.5-A scenario of comparatively high greenhouse gas emissions. Climatic Change 109, 33. https://doi.org/10.1007/s10584-011-0149-y

Smith, R.N.B., 1990: A scheme for predicting layer clouds and their water content in a general circulation model. Quart. J. Roy. Meteorol. Soc. 116, 435-460. https://doi.org/10.1002/qj.49711649210

Szentimrey, T. and Bihari, Z., 2007: Mathematical background of the spatial interpolation methods and the software MISH (Meteorological Interpolation based on Surface Homogenized Data Basis). In: Proceedings from the Conference on Spatial Interpolation in Climatology and Meteorology, Budapest, Hungary, 2004, COST Action 719, COST Office, 17-27.

Szentimrey, T., 2008: Development of MASH homogenization procedure for daily data. In: Proceedings of the Fifth Seminar for Homogenization and Quality Control in Climatological Databases, Budapest, Hungary, 2006. WCDMP-No.71, WMO/TD-No. 1493, 123-130.

Tatai, Zs., Bódi-Nagy, A., Frits, B., Pogány, A., Orosz, I., Szöke, B., and Bedöcs, B., 2018: Budapest klímastratégiája. (in Hungarian)

Tatai, Zs., Bódi-Nagy, A., Orosz, I., Becsák, P., Petö, Z., and Szabó, K., 2021: Budapest fenntartható energia- és klíma akcióterve (in Hungarian, under consultation). https://budapest.hu/Documents/klimastrategia/BP_klimastrategia_SECAP_egyeztetesi_anyag.pdf

UN, 2014: Concise Report on the World Population Situation in 2014. Department of Economic and Social Affairs, United Nations, New York, USA. ISBN 978-92-1-151518-3

Voldoire, A., Sanchez-Gomez, E., Salas y Mélia, D., Decharme, B., Cassou, C., Sénési, S., Valcke, S., Beau, I., Alias, A., Chevallier, M., Déqué, M., Deshayes, J., Douville, H., Fernandez, E., Madec, G., Maisonnave, E., Moine, M.-P., Planton, S., Saint-Martin, D., Szopa, S., Tyteca, S., Alkama, R., Belamari, S., Braun, A., Coquart, L., and Chauvin, F., 2013: The CNRM-CM5.1 global climate model: description and basic evaluation. Climate Dynam. 40, 2091-2121. https://doi.org/10.1007/s00382-011-1259-y

Wilby, R.L., 2008: Constructing Climate Change Scenarios of Urban Heat Island Intensity and Air Quality. Environ. Plan. B: Plan. Design 35, 902-919. https://doi.org/10.1068/b33066t

Zsebeházi, G. and Mahó, S.I., 2021: Assessment of the Urban Impact on Surface and Screen-Level Temperature in the ALADIN-Climate Driven SURFEX Land Surface Model for Budapest. Atmosphere 12, 709. https://doi.org/10.3390/atmos12060709

Zsebeházi, G. and Szépszó, G., 2020: Modeling the urban climate of Budapest using the SURFEX land surface model driven by the ALADIN-Climate regional climate model results. Idöjárás 124, 191207. https://doi.org/10.28974/idojaras.2020.2.3 